\title{
Stereoselective Synthesis of (-)-Cephalotaxine and C-7 Alkylated Analogues
}

\author{
Loïc Planas, Joëlle Pérard-Viret, and Jacques Royer* \\ UMR 8638 (CNRS-Université Paris-5), Faculté des Sciences Pharmaceutiques et Biologiques, \\ 4 avenue de l'Observatoire, 75270 Paris Cedex 06, France \\ jacques.royer@univ-paris5.fr
}

\begin{abstract}
A total asymmetric synthesis of (-)-cephalotaxine is reported. The chemistry of $\alpha, \beta$-unsaturated $\gamma$-lactams was used to access the 1-azaspiro[4.4]nonane skeleton in enantiomerically pure form via a stereocontrolled semipinacolic rearrangement of an $\alpha$-hydroxyiminium ion. This spiro compound was transformed into (-)-cephalotaxine without any racemization or epimerization by following the racemic synthesis reported by Kuehne. We thus performed a total synthesis of (-)cephalotaxine in $98.7 \%$ ee with an overall yield of $9.8 \%$ over a 16 steps sequence. This synthetic process was adaptable to the access of some alkylated analogues.
\end{abstract}

\section{Introduction}

(-)-Cephalotaxine 1 was isolated in 1963 from the evergreen plum yews of the genus Cephalotaxus as the most abundant alkaloid. ${ }^{1}$ Its greatest interest is the powerful activity of its ester derivatives, harringtonine $\mathbf{2 a}$ and homoharringtonine $\mathbf{2 b}$, against chronic myelogenous leukaemia (Figure 1). Homoharringtonine has thus been extensively studied and is now in phase III clinical trials. ${ }^{2}$ However, the natural source of this alkaloid remains very limited, and some species of the Asian shrub, from which it is extracted, are endangered. ${ }^{3}$ Furthermore, it should be mentioned that this material is only ca. $90 \%$ ee pure. ${ }^{4}$

Recently, an efficient hemisynthesis of enantiopure homoharringtonine from (-)-cephalotaxine has been described, ${ }^{5}$ which has increased the interest in the synthesis of this parent pentacyclic natural product. Thus, an efficient and scalable synthesis of enantiopure (-)-cephalotaxine should be quite interesting.

During the 1970 s and the 1980 s, many teams were engaged in this challenging synthesis, the main problem being the construction of the spiro quaternary center at rings $\mathbf{C}$ and $\mathbf{D}$. This led to more than 10 racemic

* Corresponding author. Tel: (33) 1537397 49. Fax: (33) 14329 1403.

(1) Paudler, W. W.; Kerley, G. I.; McKay, J. J. Org. Chem. 1963, $28,2194-2197$.

(2) For a review on HHT clinical trials: (a) Kantarjian, H. M.; Talpaz, M.; Santini, V.; Murgo, A.; Cheson, B.; O'Brien, S. M. Cancer 2001, 92, 1591-605. Most recent results: (b) Hitt, E. Lancet Oncol. 2002, 3, 259. (c) O’Brien, S.; Talpaz, M.; Cortes, J.; Shan, J.; Giles, F. J.; Faderl, S.; Thomas, D.; Garcia-Manero, G.; Mallard, S.; Beth, M.; Koller, C.; Kornblau, S.; Andreeff, M.; Murgo, A.; Keating, M.; Kantarjian, H. M. Cancer 2002, 94, 2024-32. (d) Scappini, B.; Onida, F.; Kantarjian, H. M.; Dong, L.; Verstovsek, S.; Keating, M. J.; Beran, M. Cancer 2002, 94, 2653-62.

(3) Farjon, A. World checklist and bibliography of conifers; The Royal Botanic Gardens: Kew, 1998.

(4) Huang, W.; Li, Y.; Pan, X. Sci. Sin. 1980, 23, 835-846.

(5) Robin, J.-P.; Dhal, R.; Dujardin, G.; Girodier, L.; Mevellec, L.; Poutot, S. Tetrahedron Lett. 1999, 40, 2931-2934.
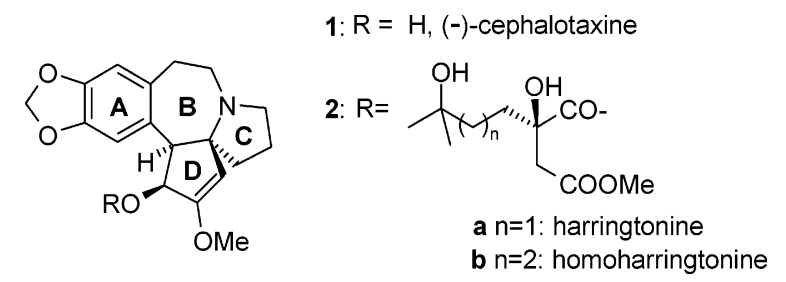

FIGURE 1. Cephalotaxus alkaloids.

syntheses and many approaches. ${ }^{6}$ There is still a pressing interest for an efficient synthesis of this structurally original alkaloid, and approaches continue to be published. ${ }^{7-9}$

In the past decade, as new developments in asymmetric organic chemistry were growing, four asymmetric syntheses were proposed. The first one, published by Mori in 1995, was based on the use of unnatural D-proline. ${ }^{10}$ Mori underlined and partially resolved the problem of racemization in the last steps since (-)-cephalotaxine was obtained with an $88 \%$ ee according to the optical rotation, while the ee of the next to last product was carefully examined and found to be $88 \%$ (chiral HPLC). In 1997, Nagasaka achieved the syntheses of both (-)- and (+)cephalotaxine by resolution of an intermediate following separation of diastereoisomeric ketal derivatives by

(6) For a review on these syntheses: Jilal Miah, M. A.; Hudlicky, T.; Reed, J. W. In The Alkaloids; Cordell, G. A., Ed.; Academic Press: San Diego, CA, 1998; Vol. 51

(7) For more recent syntheses: (a) Kim, S. H.; Cha, J. K. Synthesis 2000, 2113-2116. (b) Booker Milburn, K. I.; Dudin, L. F.; Anson, C. E Guile, S. D. Org. Lett. 2001, 3, 3005-3008. (c) Tietze, L. F.; Steck, P. L. Eur. J. Org. Chem. 2001, 4353-4356. (d) Worden, S. M.; Mapitse, R.; Hayes, C. J. Tetrahedron Lett. 2002, 43, 6011-6014.

(8) (a) Koseki, Y.; Sato, H.; Watanabe, Y.; Nagasaka, T. Org. Lett. 2002, 4, 885-888. (b) Suga, S.; Watanabe, M.; Yoshida, J.-i. J. Am. Chem. Soc. 2002, 124, 14824-14825.

(9) Li, W.-D. Z.; Wang, Y.-Q. Org. Lett. 2003, 5, 2931-2934. In this paper, the resolution of the next to last intermediate furnished (-)cephalotaxine.

(10) Isono, N.; Mori, M. J. Org. Chem. 1995, 60, 115-119. 


\section{SCHEME 1}

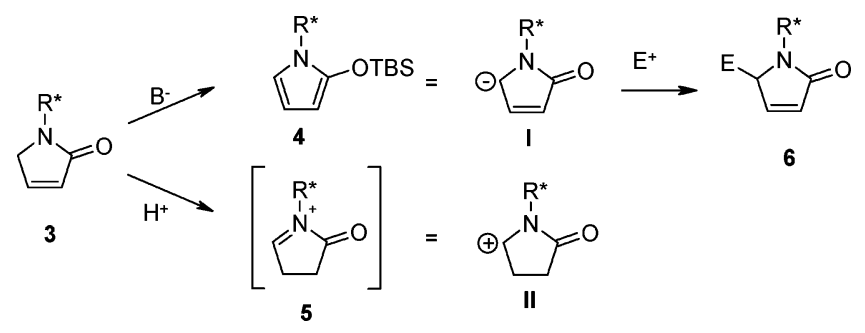

HPLC. ${ }^{9}$ Though no details were given in this report, the optical rotation of the target product corresponds to a high enantiomeric purity. In 1999, Ikeda published a synthesis from unnatural D-proline, ${ }^{12}$ while Tietze performed an elegant and very efficient asymmetric synthesis based on palladium chemistry. ${ }^{13}$ These syntheses were formal syntheses, and the ee of the last described intermediate was limited to $85-90 \%$.

In this context, we wish to report herein a new scalable and highly efficient asymmetric synthesis of (-)-cephalotaxine in $98.7 \%$ ee. This synthesis is based on the stereoselective spirocyclization we reported in a previous communication. ${ }^{14}$ We will describe herein the overall synthesis and a careful determination of the enantiomeric purity of (-)-cephalotaxine together with some C-7alkylated cephalotaxine derivatives.

\section{Results and Discussion}

The strategy we chose was focused on the achievement of a method for the construction of the $\mathbf{C} / \mathbf{D}$ ring moiety of $\mathbf{1}$ and more precisely to develop an efficient access to the 1-azaspiro[4.4]nonane skeleton in an asymmetric fashion. This project was based upon the chemistry of $\alpha, \beta$-unsaturated $\gamma$-lactams 3 we have developed for some years in the laboratory. These compounds were thought to be of particular interest in the asymmetric construction of a quaternary center $\alpha$ to the nitrogen of the pyrrolidine ring and hence a spiro derivative. Indeed, depending upon the conditions, these $\alpha, \beta$-unsaturated $\gamma$-lactams 3 are equivalent to either the carbanion synthon $\mathbf{I}$ or the carbocation synthon II as depicted in the Scheme 1.

Silyloxypyrrole 4, equivalent to carbanion synthon I, reacts with electrophiles at C-5 to furnish 6 . This last compound possesses the $\alpha, \beta$-unsaturated lactam function from which a new reaction at the same center is possible through the anionic or cationic species.

We turned our attention to the semipinacolic rearrangement investigated by Paquette ${ }^{15}$ through $\alpha$-hydroxyoxonium and applied to $\alpha$-hydroxyiminium by Dake. ${ }^{16}$ We described in a previous communication the use of this rearrangement in the $\alpha, \beta$-unsaturated $\gamma$-lactam series. ${ }^{14}$ We showed that stereocontrolled rearrange-

(11) Nagasaka, T.; Sato, H.; Saeki, S.-I. Tetrahedron: Asymmetry 1997, 8, 191-194.

(12) Ikeda, M.; el Bialy, S. A.; Hirose, K.; Kotake, M.; Sato, T.; Bayomi, S. M.; Shehata, I. A.; Abdelal, A. M.; Gad, L. M.; Yakura, T. Chem. Pharm. Bull. 1999, 47, 983-7.

(13) Tietze, L. F.; Schirok, H. J. Am. Chem. Soc. 1999, 121, 1026410269

(14) Planas, L.; Pérard-Viret, J.; Royer, J.; Selkti, M.; Tomas, A Synlett 2002, 1629-1632.

(15) (a) Paquette L. A.; Negri J. T.; Rogers R. D. J. Org. Chem. 1992 57, 3947-3956. (b) Paquette L. A.; Lanter J. C.; Jonhston J. N. J. Org. Chem. 1997, 62, 1702-1712. (c) Paquette L. A.; Kiney M. J.; Dullweber U. J. Org. Chem. 1997, 62, 1713-1722.

\section{SCHEME 2}
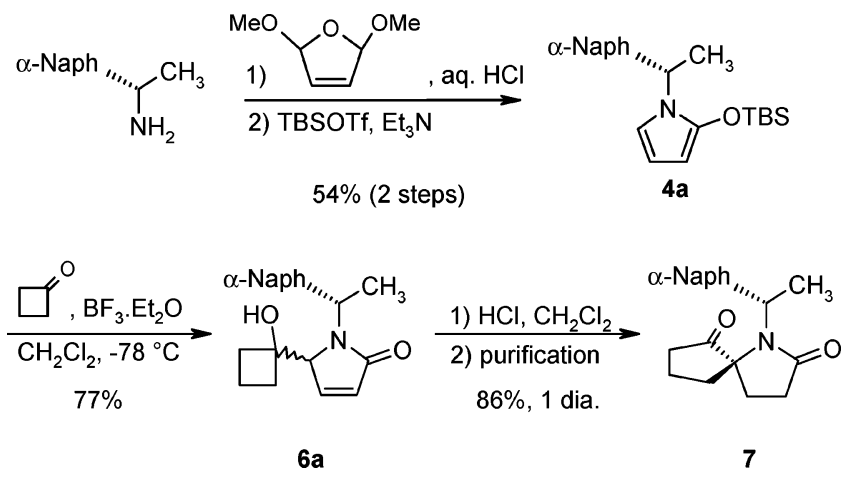

SCHEME 3

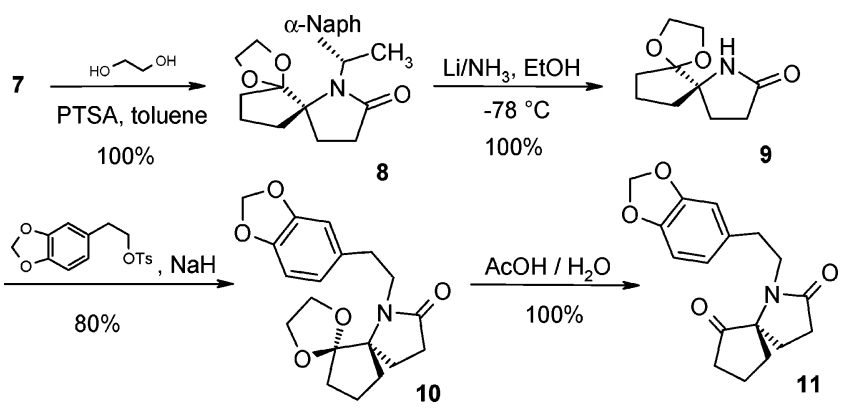

ment could be attained by the use of chiral auxiliary on the nitrogen atom, and we selected (S)-1-(1-naphthyl)ethylamine as the most efficient chiral appendage and starting material.

Thus, starting from $(S)$-1-(1-naphthyl)ethylamine, we prepared the silyloxypyrrole $\mathbf{4 a}$ in $54 \%$ yield (after purification) over two steps as described in Scheme 2. The vinylogous Mukaiyama aldol reaction of $\mathbf{4 a}$ with cyclobutanone affords the $\alpha, \beta$-unsaturated $\gamma$-lactam $\mathbf{6 a}$ with $77 \%$ yield but only $4 \%$ diastereoisomeric excess. Acidic treatment of $\mathbf{6 a}$ (concentrated $\mathrm{HCl}$ in $\mathrm{CH}_{2} \mathrm{Cl}_{2}$ at 0 ${ }^{\circ} \mathrm{C}$ ) furnished the desired spiro compound $\mathbf{7}$ in quantitative yield with a good diastereoisomeric excess (80\%).

Besides this good de, it was found that the two diastereoisomers can be very easily separated. Indeed, the major diastereoisomer was crystallized from ethanol furnishing $69 \%$ yield of pure compound as shown from ${ }^{1} \mathrm{H}$ NMR analyses. Additional product could be obtained after flash chromatography on silica gel of the mother liquor, giving almost the totality of the major diastereoisomer. The spiro compound $\mathbf{7}$ exhibiting the required configuration was then obtained in $86 \%$ yield.

Cephalotaxine Total Synthesis Achievement. To perform the cleavage of the chiral appendage, the ketone function of $\mathbf{7}$ was protected as the cyclic ketal $\mathbf{8}$, using ethylene glycol under standard conditions (Scheme 3). Reductive cleavage of the $N$-benzylic bond of $\mathbf{8}$ was then performed with lithium in liquid ammonia, and the bispiro lactam 9 was isolated in quantitative yield over the two steps. This material was used without purification through the next step, which consisted of $N$-alkylation with the tosylate of 3,4-methylenedioxypheny-2ethanol $^{11}$ to give $\mathbf{1 0}$ in $80 \%$ yield after purification.

(16) (a) Fenster M. D. E.; Patrick B. O.; Dake G. R. Org. Lett. 2001 3, 2109-2112. (b) Fenster M. D. E.; Dake G. R. Org. Lett. 2003, 5, $4313-4316$. 


\section{SCHEME 4}

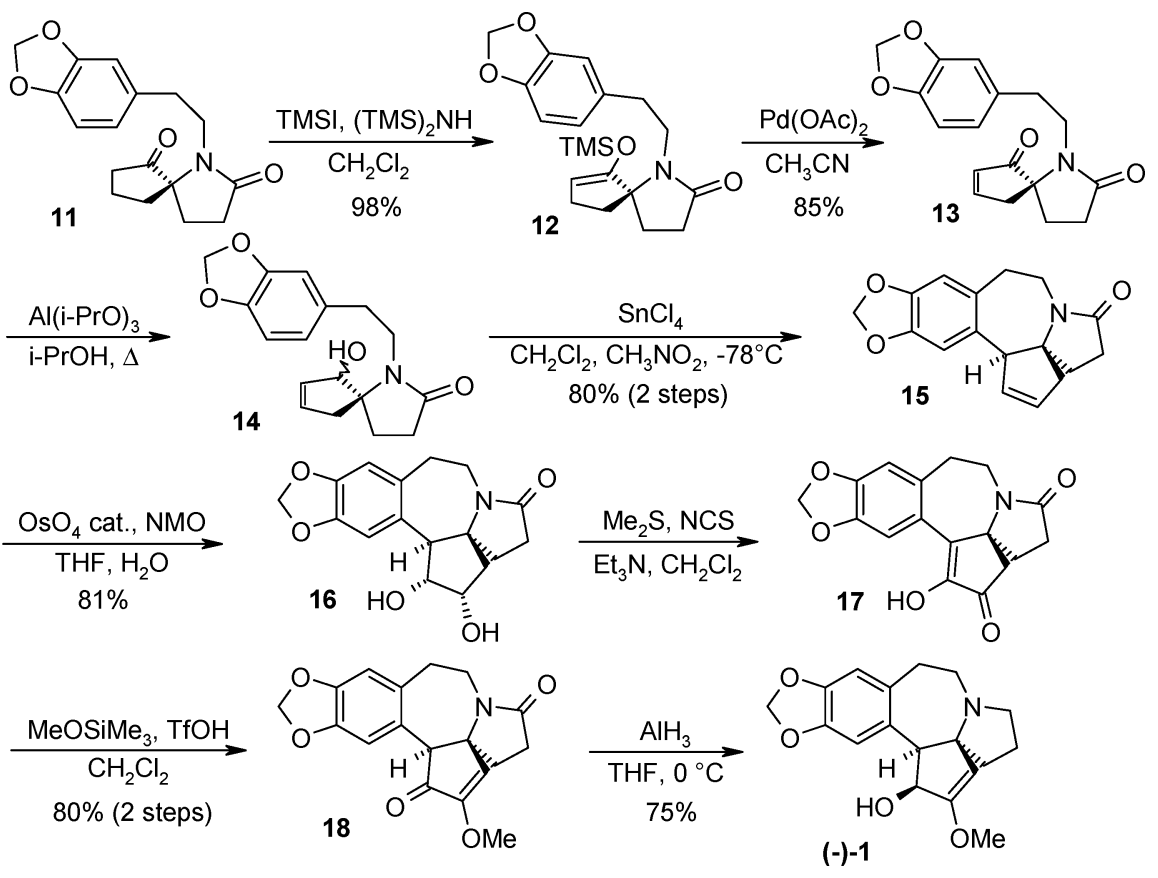

Deprotection of $\mathbf{1 0}$ in acidic medium finally provides $\mathbf{1 1}$ in a quantitative yield (Scheme 3).

Eventually, enantiopure $\mathbf{1 1}$ was transformed to (-)-cephalotaxine following the procedure used by Kuehne for his racemic synthesis and summarized in Scheme 4. It consists of eight steps with an overall yield of $69 \%$.

In our hands, the synthesis was achieved with an overall yield of $32 \%$. Only two minor changes were done. First, we found that there is no need, in the oxidation reaction of $\mathbf{1 2}$ to 13 , to have benzoquinone in addition with palladium acetate since the latter is used in a stoichiometric amount. ${ }^{17}$ The second change was concerned with the last step, which we have to perform very carefully due to the sensitivity of cephalotaxine to racemization. Though no clear racemization mechanism was proposed, cephalotaxine is known to be sensitive to acidic conditions. That could explain why natural cephalotaxine was not isolated as an enantiomerically pure compound. It was reported that the methyl iodide derivative 19 (Y $=\mathrm{CH}_{3}$, Scheme 5), prepared from natural cephalotaxine, was obtained in a racemic form. ${ }^{18}$ The equilibrium between 19 and an open form like 20, having lost all asymmetric carbons, might be responsible for this racemization (Scheme 5). Such a reaction may arise upon treatment of cephalotaxine with acid (Brönsted or Lewis acid).

Thus, we decided to change the conditions described by Kuehne ( $\mathrm{LiAlH}_{4}$ in refluxing THF), and instead, we used the more reactive aluminum hydride that allows us achieve the reaction at $0{ }^{\circ} \mathrm{C}$. In addition, the reduction of $\gamma$-lactams is described to be cleaner with this reagent. ${ }^{19}$ These conditions furnished a $75 \%$ yield of (-)-cephalo-

(17) Ito, Y.; Suginome, M. In Handbook of Organopalladium Chemistry for Organic Synthesis; Negishi, E.-i., Ed.; John Wiley \& Sons: New York, 2002; pp 2873-2879.

(18) Abraham, D. J.; Rosenstein, R. D.; McGandy, E. L. Tetrahedron Lett. 1969, 10, 4085-4086.

(19) Meyers, A. I.; Burgess, L. E. J. Org. Chem. 1991, 56, 22942296.

\section{SCHEME 5}

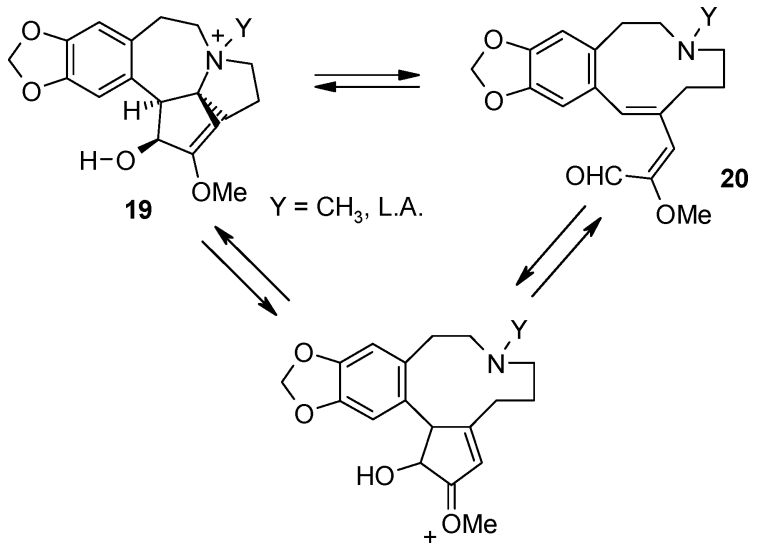

taxine $\left[[\alpha]{ }^{20}{ }_{\mathrm{D}}-182\left(\mathrm{CHCl}_{3}, c=0.21\right)\left(\right.\right.$ lit. ${ }^{20}[\alpha]{ }^{20}{ }_{\mathrm{D}}-188$ $\left.\left.\left(\mathrm{CHCl}_{3}\right)\right)\right]$.

We then determined the enantiomeric purity of this synthetic material. It could be easily analyzed by means of chiral HPLC, but for doing so we needed both enantiomers. Thus, we first studied a cephalotaxine sample obtained from a natural source which classically contained 5-10\% (+)-cephalotaxine. ${ }^{4}$ This analysis (Chiral HPLC/MS spectrometry) proved that the natural sample has an enantiomeric purity of $83 \%$. Using the same HPLC conditions, we could determine that our synthetic sample contains $0.65 \%$ of $(+)$-cephalotaxine and hence $(-)$-cephalotaxine was prepared in $98.7 \%$ enantiomeric purity. It is noteworthy that the enantiomeric purity of this material corresponds to that of (S)-1-(1-naphthyl)ethylamine, which was used as chiral inducer and source of nitrogen.

C-7-Alkylated Analogues. The asymmetric synthesis we performed allowed us to achieve the synthesis of some

(20) Arora, S. K.; Bates, R. B.; Grady, R. A.; Powell, R. G. J. Org. Chem. 1974, 39, 1269-1271. 


\section{SCHEME 6}

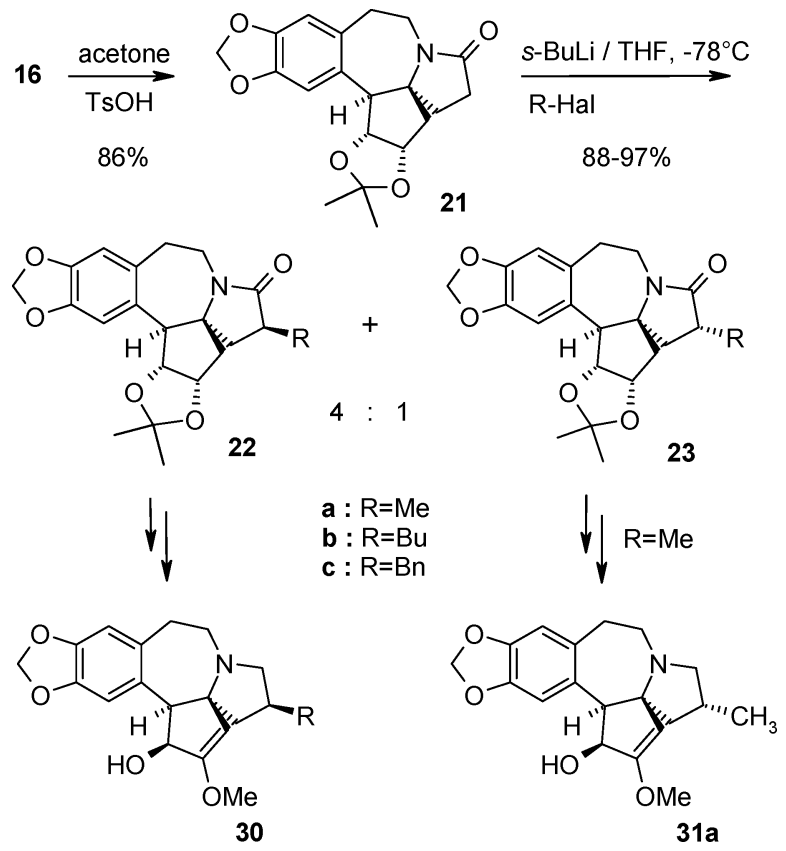

analogues through the alkylation of the pyrrolidine ring of the alkaloid. A few approaches to the preparation of analogues of cephalotaxine were reported. They were mainly concerned with modification of the aromatic $\mathbf{A}$ ring (dimethoxypheny ${ }^{21}$ and indole ${ }^{22}$ in place of methylenedioxyphenyl group) or change of the size of the $\mathbf{B}$, $\mathbf{C}$, or $\mathbf{D}$ ring to a six-membered ring as reported by Tietze showing the versatility of his method. ${ }^{23}$ But, to the best of our knowledge, only one analogue of cephalotaxine was reported: it consists of the change to dimethoxyphenyl instead of the methylenedioxyphenyl group. ${ }^{21}$

Cephalotaxine analogues might be useful for accessing homoharringtonine analogues whose antitumoral activity should be evaluated. We planned to introduce alkyl substituents on the $\mathbf{C}$ ring in order to investigate what spatial surrounding is compatible with the biological activity. To attain several analogues, it appears necessary to be able to introduce a substituent quite late in the synthesis. We thus thought that alkylation of lactam $\mathbf{1 6}$ after protection of the diol moiety would be suitable.

The diol $\mathbf{1 6}$ was protected as an acetonide using standard conditions to give $\mathbf{2 1}$ in $86 \%$ yield (Scheme 6). Alkylation of $\mathbf{2 1}$ was achieved through deprotonation using $s$-BuLi in THF at $-78{ }^{\circ} \mathrm{C}$ and addition of MeI, BuI, and $\mathrm{PhCH}_{2} \mathrm{Br}$ to provide diastereomeric alkylated lactams 22 and 23 in $88-97 \%$ yield and in a 4:1 ratio. The $(S)$-configuration of the new chiral center of the major isomer 22 was determined through ${ }^{1} \mathrm{H}$ NMR NOE experiments and could be easily explained by the geometry of the tetracyclic compound. In each series, the diastereoisomers could be separated by flash chromatography. Major diastereoisomers $\mathbf{2 2 a}-\mathbf{c}$ were deprotected to the corresponding diol, and then the alkylated cepha-

(21) Yasuda, S.; Yamada, T.; Hanaoka, M. Tetrahedron Lett. 1986 27, 2023-2026.

(22) Noe, E.; Seraphin, D.; Qiang, Z.; Djate, F.; Henin, J.; Laronze, J.-Y.; Levy, J. Tetrahedron Lett. 1996, 37, 5701-5704.

(23) (a) Tietze, L. F.; Schirok, H.; Wohrmann, M. Chemistry 2000 6, 510-518. (b) Tietze, L. F.; Schirok, H.; Wohrmann, M.; Schrader, K. Eur. J. Org. Chem. 2000, 2433-2444. lotaxines 30a-c were obtained by application of the last three steps of the synthesis of cephalotaxine with the same yields as for the parent compound. Minor epimer 23a was also transformed to $\mathbf{3 1 a}$.

\section{Conclusion}

By using an original and efficient stereoselective access to 1-azaspiro[4.4]nonane compounds, and following the Kuehne synthesis for the end of the sequence, we reported an asymmetric synthesis of (-)-cephalotaxine in $98.7 \%$ ee with an overall yield of $9.8 \%$ over a 16 -step sequence. It thus proved the relevance of the chemistry of $\alpha, \beta$-unsaturated $\gamma$-lactams for the synthesis of complex alkaloids. This synthetic sequence is adaptable for access to some alkylated analogues.

\section{Experimental Section}

(1'S)-1-(1'-(1-Naphthyl)ethyl)-2-tert-butyldimethylsilyloxy-1H-pyrrole (4a). To a solution of (S)-1-(1-naphthyl)ethylamine (3.42 g, $26.28 \mathrm{mmol})$ and 2,5-dimethoxy-2,5dihydrofuran $(3.00 \mathrm{~g}, 17.52 \mathrm{mmol})$ in water $(70 \mathrm{~mL}, 0.25 \mathrm{M})$ was added a concentrated aqueous solution of $\mathrm{HCl}(2.32 \mathrm{~mL}$, $26.28 \mathrm{mmol}$ ). The reaction mixture was stirred at $\mathrm{rt}$ for $1 \mathrm{~h}$, neutralized with solid $\mathrm{NaHCO}_{3}$, and extracted with $\mathrm{CH}_{2} \mathrm{Cl}_{2}$. The combined organic layers were dried over $\mathrm{Na}_{2} \mathrm{SO}_{4}$ and concentrated under vacuum. A red oily mixture of the $\alpha, \beta$ - and $\beta, \gamma$-unsaturated lactams was then obtained. To a solution of this crude product (ca. $17.52 \mathrm{mmol})$ and $\mathrm{NEt}_{3}(3.50 \mathrm{~g}, 35 \mathrm{mmol})$ in $\mathrm{CH}_{2} \mathrm{Cl}_{2}$ (35 mL, $0.5 \mathrm{M}$ ) was slowly added tert-butyldimethylsilyl triflate $(4.86 \mathrm{~g}, 18.40 \mathrm{mmol})$. The reaction mixture was stirred at rt for $1 \mathrm{~h}$, and the solvent was then evaporated. The residue was purified by filtration on a pad of alumina (heptane/ AcOEt 88/12), providing $\mathbf{4 a}$ (3.50 g, 57\% for two steps) as a slightly colored solid. $\mathrm{Mp}=97{ }^{\circ} \mathrm{C}$ (heptane-AcOEt). ${ }^{1} \mathrm{H}$ NMR $\left(300 \mathrm{MHz}, \mathrm{CDCl}_{3}\right): \delta=-0.05(\mathrm{~s}, 3 \mathrm{H}), 0.23(\mathrm{~s}, 3 \mathrm{H}), 0.80(\mathrm{~s}$, $9 \mathrm{H}), 1.89(\mathrm{~d}, J=7.0 \mathrm{~Hz}, 3 \mathrm{H}), 5.31$ (dd, $J=3.6,2.0 \mathrm{~Hz}, 1 \mathrm{H})$, $6.01(\mathrm{t}, J=3.5 \mathrm{~Hz}, 1 \mathrm{H}), 6.16(\mathrm{q}, J=7.0 \mathrm{~Hz}, 1 \mathrm{H}), 6.35(\mathrm{dd}, J$ $=3.4,1.9 \mathrm{~Hz}, 1 \mathrm{H}), 7.10(\mathrm{~d}, J=7.2 \mathrm{~Hz}, 1 \mathrm{H}), 7.42(\mathrm{t}, J=7.9$ $\mathrm{Hz}, 1 \mathrm{H}), 7.50-7.55(\mathrm{~m}, 2 \mathrm{H}), 7.77(\mathrm{~d}, J=8.3 \mathrm{~Hz}, 1 \mathrm{H}), 7.88(\mathrm{~d}$, $J=7.4 \mathrm{~Hz}, 1 \mathrm{H}), 8.08(\mathrm{~d}, J=8.0 \mathrm{~Hz}, 1 \mathrm{H}) .{ }^{13} \mathrm{C} \mathrm{NMR}(75 \mathrm{MHz}$, $\left.\mathrm{CDCl}_{3}\right): \delta=-5.0,-4.6,18.2,21.4,25.7,49.5,87.7,105.2$, $109.8,123.2,125.8,126.5,128.1,129.1,131.0,134.1,139.7$, 142.2. IR (KBr): $v=2929,2858,1560,1492,1438 \mathrm{~cm}^{-1} \cdot[\alpha]^{25} \mathrm{D}$ : $+11.7\left(c=0.69, \mathrm{CH}_{2} \mathrm{Cl}_{2}\right)$. HRMS $\left(\mathrm{CI}, \mathrm{NH}_{3},[\mathrm{MH}]^{+}\right): \mathrm{m} / z$ calcd 352.2097 , found 352.2101 .

(1'S)-5-(1-Hydroxycyclobutyl)-1-(1'-(1-naphthyl)ethyl)1,5-dihydropyrrol-2-one (6a). To a solution of $4 \mathbf{a}(4.17 \mathrm{~g}$, $11.86 \mathrm{mmol})$ in anhydrous $\mathrm{CH}_{2} \mathrm{Cl}_{2}(80 \mathrm{~mL}, 0.15 \mathrm{M})$ containing $3 \AA \mathrm{MS}$ was added, under argon, cyclobutanone $(1.43 \mathrm{~mL}, 18.98$ $\mathrm{mmol}$ ). After $15 \mathrm{~min}$ at $\mathrm{rt}$, the solution was cooled at $-78^{\circ} \mathrm{C}$, and $\mathrm{BF}_{3} \cdot \mathrm{Et}_{2} \mathrm{O}(2.25 \mathrm{~mL}, 17.79 \mathrm{mmol})$ was added over the course of $15 \mathrm{~min}$. The solution was stirred at $-78^{\circ} \mathrm{C}$ for $2 \mathrm{~h}$, filtered, and allowed to warm to $0^{\circ} \mathrm{C}$. The reaction was then quenched by addition of water. An insoluble compound could be then filtered giving $0.94 \mathrm{~g}$ of the pure minor diastereoisomer. The aqueous phase was separated and extracted with $\mathrm{CH}_{2} \mathrm{Cl}_{2}$. The crude mixture obtained after drying and evaporation of the solvent was triturated with ether. A $1.48 \mathrm{~g}$ crop of crystals consisting of the major diastereoisomer was thus obtained. From the residue, $0.40 \mathrm{~g}$ of a diastereoisomeric mixture was obtained after flash chromatography $\left(\mathrm{CH}_{2} \mathrm{Cl}_{2} /\right.$ $\mathrm{MeOH}, 96 / 4$ ). Finally, compound $6 \mathbf{a}$ was obtained in a $77 \%$ combined yield. Major Diastereoisomer. $\mathrm{Mp}=196-198^{\circ} \mathrm{C}$ $\left(\mathrm{Et}_{2} \mathrm{O}\right) .{ }^{1} \mathrm{H}$ NMR $\left(300 \mathrm{MHz}, \mathrm{CDCl}_{3}\right): \delta=1.36(\mathrm{~m}, 1 \mathrm{H}), 1.8-$ $2.1(\mathrm{~m}, 5 \mathrm{H}), 1.75(\mathrm{~s}, 1 \mathrm{H}), 1.86(\mathrm{~d}, J=7.0 \mathrm{~Hz}, 3 \mathrm{H}), 3.51$ (t, $J=$ $1.5 \mathrm{~Hz}, 1 \mathrm{H}), 6.07(\mathrm{q}, J=7.0 \mathrm{~Hz}, 1 \mathrm{H}), 6.28(\mathrm{dd}, J=6.0,1.6 \mathrm{~Hz}$, $1 \mathrm{H}), 6.81$ (dd, $J=6.0,1.8 \mathrm{~Hz}, 1 \mathrm{H}), 7.47(\mathrm{~m}, 3 \mathrm{H}), 7.63(\mathrm{~m}, 2 \mathrm{H})$, $7.84(\mathrm{~m}, 2 \mathrm{H}) .{ }^{13} \mathrm{C} \mathrm{NMR}\left(75 \mathrm{MHz}, \mathrm{CDCl}_{3}\right): \delta=13.6,19.1,31.9$, $36.2,49.0,69.6,75.9,123.2,125.2,125.8,126.1,127.3,128.5$, 
129.1, 129.2, 132.0, 134.0, 136.2, 145.7, 173.3. IR (KBr): $v=$ $3382,2977,2934,1658,1394 \mathrm{~cm}^{-1}$. Anal. Calcd for $\mathrm{C}_{20} \mathrm{H}_{21}-$ $\mathrm{NO}_{2}$ : C, 78.15; H, 6.89; N, 4.56. Found: C, 78.03; H, 7.06; N, 4.60. MS (CI, $\left.\mathrm{NH}_{3}\right): m / z=308\left(\mathrm{MH}^{+}\right), 238\left(\mathrm{MH}^{+}-\mathrm{C}_{4} \mathrm{H}_{6} \mathrm{O}\right)$. $\left[\alpha{ }^{25}{ }_{\mathrm{D}}-13.8\left(c=0.97, \mathrm{CHCl}_{3}\right)\right.$. Minor Diastereoisomer. $\mathrm{Mp}$ $=245{ }^{\circ} \mathrm{C}\left(\mathrm{CH}_{2} \mathrm{Cl}_{2}\right) \cdot{ }^{1} \mathrm{H}$ NMR $\left(300 \mathrm{MHz}, \mathrm{CDCl}_{3}\right): \delta=0.35-0.5$ (m, $1 \mathrm{H}), 1.01\left(\mathrm{~s}, 1 \mathrm{H}, \mathrm{D}_{2} \mathrm{O}\right.$ exch), $1.35-1.55(\mathrm{~m}, 2 \mathrm{H}), 1.55-1.7$ $(\mathrm{m}, 2 \mathrm{H}), 1.78(\mathrm{~d}, J=7.1 \mathrm{~Hz}, 3 \mathrm{H}), 1.85-2.0(\mathrm{~m}, 1 \mathrm{H}), 4.25(\mathrm{t}, J$ $=1.6 \mathrm{~Hz}, 1 \mathrm{H}), 6.30(\mathrm{~m}, 2 \mathrm{H}), 6.94(\mathrm{dd}, J=7.0,6.0 \mathrm{~Hz}, 1 \mathrm{H})$, 7.4-7.6 (m, 4H), $7.83(\mathrm{~d}, J=8.1 \mathrm{~Hz}, 1 \mathrm{H}), 7.90(\mathrm{~d}, J=8.3 \mathrm{~Hz}$, $1 \mathrm{H}), 8.23(\mathrm{~d}, J=8.4 \mathrm{~Hz}, 1 \mathrm{H}) .{ }^{13} \mathrm{C}$ NMR $(75 \mathrm{MHz}, \mathrm{DMSO}): \delta$ $=17.7,24.4,36.2,40.6,55.1,74.8,81.3,128.5,130.3,130.8$, $131.7,132.9,134.3,134.5,136.1,139.0,143.5,151.3,177.6$. IR (KBr): $v=3388,2976,2937,1660 \mathrm{~cm}^{-1} . \mathrm{MS}\left(\mathrm{CI}, \mathrm{NH}_{3}\right): \mathrm{m} / z$ $=308\left(\mathrm{MH}^{+}\right), 238\left(\mathrm{MH}^{+}-\mathrm{C}_{4} \mathrm{H}_{6} \mathrm{O}\right) .[\alpha]^{25}{ }_{\mathrm{D}}:-264.1(c=0.52$, $\left.\mathrm{CHCl}_{3}\right)$.

(5R)-(1'S)-1-(1'-(1-Naphthyl)ethyl)-1-azaspiro[4.4]nonane-2,6-dione (7). To a solution of 6a (13.30 g, 43.27 mmol) in $\mathrm{CH}_{2} \mathrm{Cl}_{2}(930 \mathrm{~mL}, 0.05 \mathrm{M})$ at $0{ }^{\circ} \mathrm{C}$ was added concentrated aqueous $\mathrm{HCl}(6.14 \mathrm{~mL}, 64.90 \mathrm{mmol})$. After $24 \mathrm{~h}$ at $0{ }^{\circ} \mathrm{C}$, the solution was allowed to warm to $\mathrm{rt}$, and the solvent was removed under vacuum. The crude product was redissolved in $\mathrm{CH}_{2} \mathrm{Cl}_{2}$ and reevaporated twice to eliminate trace amount of acid and provide $\mathbf{7}$ (13.30 g, quant) as an amorphous solid. The pure major diastereomer of 7 (9.17 g, 86\%) was obtained by crystallization in $40 \mathrm{~mL}$ of $95 \% \mathrm{EtOH}$ and by flash chromatography of the mother liquor (silica gel; AcOEt/ cyclohexane 50/50). $\mathrm{Mp}=140{ }^{\circ} \mathrm{C}\left(\mathrm{Et}_{2} \mathrm{O}\right) .{ }^{1} \mathrm{H} \mathrm{NMR}(400 \mathrm{MHz}$, $\left.\mathrm{CDCl}_{3}\right): \delta=1.07-1.17(\mathrm{~m}, 2 \mathrm{H}), 1.34-1.55(\mathrm{~m}, 2 \mathrm{H}), 1.62$ (ddd, $J=12.3,8.5,6.5 \mathrm{~Hz}, 1 \mathrm{H}), 1.67(\mathrm{~d}, J=7.0 \mathrm{~Hz}, 3 \mathrm{H}), 1.87$ (ddd, $J=18.9,11.6,9.5 \mathrm{~Hz}, 1 \mathrm{H}), 1.93(\mathrm{ddd}, J=12.3,8.9,6.8 \mathrm{~Hz}$, $1 \mathrm{H}), 2.23(\mathrm{dd}, J=18.9,6.1 \mathrm{~Hz}, 1 \mathrm{H}), 2.43(\mathrm{ddd}, J=16.8,8.5$, $6.8 \mathrm{~Hz}, 1 \mathrm{H}), 2.53$ (ddd, $J=16.8,8.9,6.5 \mathrm{~Hz}, 1 \mathrm{H}), 6.25(\mathrm{q}, J=$ $7.1 \mathrm{~Hz}, 1 \mathrm{H}), 7.3-7.6(\mathrm{~m}, 4 \mathrm{H}), 7.83(\mathrm{~d}, J=9.7 \mathrm{~Hz}, 1 \mathrm{H}), 7.79(\mathrm{~d}$, $J=7.6 \mathrm{~Hz}, 1 \mathrm{H}), 8.00(\mathrm{~d}, J=8.3 \mathrm{~Hz}, 1 \mathrm{H}) .{ }^{13} \mathrm{C} \mathrm{NMR}(75 \mathrm{MHz}$, $\left.\mathrm{CDCl}_{3}\right): \delta=7.8,18.9,29.0,31.7,32.3,35.7,47.5,72.3,124.0$, $125.1,125.9,126.3,127.2,129.1,129.3,132.7,133.9,136.1$, 175.7, 217.0. IR (KBr): $v=2968,1750,1679,1380,1347,780$ $\mathrm{cm}^{-1}$. $\mathrm{MS}\left(\mathrm{CI}, \mathrm{NH}_{3}\right): \mathrm{m} / z=308\left(\mathrm{MH}^{+}\right)$. Anal. Calcd for $\mathrm{C}_{20} \mathrm{H}_{21^{-}}$ $\mathrm{NO}_{2}$ : C, 78.15; H, 6.89; N, 4.56. Found: C, 77.96; H, 7.15; N, 4.41. $[\alpha]^{25} \mathrm{D}:-48.4\left(c=1.04, \mathrm{CHCl}_{3}\right)$.

(6R)-(1'S)-7-(1'-(1-naphthyl)phenylethyl)-1,4-dioxa-7azadispiro[4.0.4.3]tridecan-8-one (8). To a solution of 7 (10.63 g, $34.58 \mathrm{mmol})$ in toluene $(120 \mathrm{~mL}, 0.2 \mathrm{M})$ were added ethylene glycol (19,33 mL, $346 \mathrm{mmol})$ and PTSA (0.66 g, 3.46 $\mathrm{mmol})$. The reaction mixture was refluxed in a Dean-Stark apparatus overnight, cooled to rt, poured in a saturated aqueous solution of $\mathrm{NaHCO}_{3}$, and extracted with $\mathrm{CH}_{2} \mathrm{Cl}_{2}$. The organic phase was dried over $\mathrm{Na}_{2} \mathrm{SO}_{4}$ and concentrated under vacuum, providing 8 (12.15 g, quant) as a beige solid. An analytical sample was obtained by recrystallization in $i-\mathrm{Pr}_{2} \mathrm{O}$. $\mathrm{Mp}=99{ }^{\circ} \mathrm{C}\left(i-\mathrm{Pr}_{2} \mathrm{O}\right) .{ }^{1} \mathrm{H}$ NMR $\left(300 \mathrm{MHz}, \mathrm{CDCl}_{3}\right): \delta=1.5-$ $1.65(\mathrm{~m}, 2 \mathrm{H}), 1.65-1.85(\mathrm{~m}, 4 \mathrm{H}), 1.90(\mathrm{~d}, J=7.3 \mathrm{~Hz}, 3 \mathrm{H}), 2.13$ $(\mathrm{m}, 1 \mathrm{H}), 2.35-2.5(\mathrm{~m}, 3 \mathrm{H}), 2.67$ (ddd, $J=16.3,10.7,8.7 \mathrm{~Hz}$, $1 \mathrm{H}), 3.0-3.2(\mathrm{~m}, 2 \mathrm{H}), 3.48(\mathrm{~m}, 1 \mathrm{H}), 5.70(\mathrm{q}, J=7.3 \mathrm{~Hz}, 1 \mathrm{H})$, $7.35-7.5(\mathrm{~m}, 2 \mathrm{H}), 7.52(\mathrm{dt}, J=1.3,8.2 \mathrm{~Hz}, 1 \mathrm{H}), 7.69(\mathrm{~d}, 1 \mathrm{H})$, $7.83(\mathrm{~d}, 1 \mathrm{H}), 7.95(\mathrm{t}, J=8.5 \mathrm{H}, 1 \mathrm{~Hz}) .{ }^{13} \mathrm{C}$ NMR $(100 \mathrm{MHz}$, $\left.\mathrm{CDCl}_{3}\right): \delta=16.4,20.4,30.6,30.8,31.9,32.2,51.5,63.6,65.3$, $72.7,116.9,123.2,125.2,125.3,125.9,126.2,127.2,129.2$, $130.5,133.8,140.5,178.5$. IR $(\mathrm{KBr}): v=3057,2973,2864$, 1690, $1361 \mathrm{~cm}^{-1}$. MS (CI, NH $)_{3}: m / z=352\left(\mathrm{MH}^{+}\right) .[\alpha]^{25} \mathrm{D}$ $+163.0\left(c=1.08, \mathrm{CHCl}_{3}\right)$. Anal. Calcd for $\mathrm{C}_{22} \mathrm{H}_{25} \mathrm{NO}_{3}$ : C, 75.19; H, 7.17; N, 3.99. Found: C, 74.44; H, 7.14; N, 3.68.

(6R)-1,4-Dioxa-7-azadispiro[4.0.4.3] tridecan-8-one (9). To a cooled $\left(-78{ }^{\circ} \mathrm{C}\right)$ solution of $\mathbf{8}(2.30 \mathrm{~g}, 6.51 \mathrm{mmol})$ in THF (32 $\mathrm{mL}, 0.2 \mathrm{M})$, in a flask equipped with a cold trap $\left(-78^{\circ} \mathrm{C}\right)$, was condensed ammonia (about $60 \mathrm{~mL}$ ). To the mixture was added lithium $(0.60 \mathrm{~g}, 0.086 \mathrm{~mol})$ portionwise until persistent dark blue colorization of the solution occurred. The reaction mixture was stirred for $30 \mathrm{~min}$ and allowed to warm to $\mathrm{rt}$ (evaporating thus ammonia). It was poured into an aqueous saturated solution of $\mathrm{NH}_{4} \mathrm{Cl}$ and extracted with $\mathrm{CH}_{2} \mathrm{Cl}_{2}$. The organic phase was dried over $\mathrm{Na}_{2} \mathrm{SO}_{4}$ and concentrated under vacuum. The crude product was purified by filtration through a pad of silica gel $\left(\mathrm{CH}_{2} \mathrm{Cl}_{2} / \mathrm{Et}_{3} \mathrm{~N} 99 / 1\right.$ and then $\mathrm{CH}_{2} \mathrm{Cl}_{2} / \mathrm{MeOH} /$ $\left.\mathrm{Et}_{3} \mathrm{~N} 95 / 5 / 1\right)$, providing 9 (1.28 g, quant) as a white solid. An analytical sample was obtained by recrystallization in EtOH. $\mathrm{Mp}=75-76{ }^{\circ} \mathrm{C}(\mathrm{EtOH}) .{ }^{1} \mathrm{H} \mathrm{NMR}\left(300 \mathrm{MHz}, \mathrm{CDCl}_{3}\right): \delta=1.6-$ $1.95(\mathrm{~m}, 7 \mathrm{H}), 2.25-2.55(\mathrm{~m}, 3 \mathrm{H}), 3.8-4.0(\mathrm{~m}, 4 \mathrm{H}), 6.13(\mathrm{bs}$, $1 \mathrm{H}) .{ }^{13} \mathrm{C} \mathrm{NMR}\left(75 \mathrm{MHz}, \mathrm{CDCl}_{3}\right): \delta=16.6,29.9,30.8,32.0$, 35.7, 65.3, 66.2, 68.1, 116.6, 178.2. IR (KBr): $v=2974,1667$, $1153 \mathrm{~cm}^{-1} \cdot \mathrm{MS}\left(\mathrm{CI}, \mathrm{NH}_{3}\right): \mathrm{m} / z=198\left([\mathrm{MH}]^{+}\right), 215([\mathrm{M}+$ $\left.\left.\mathrm{NH}_{4}\right]^{+}\right) .[\alpha]^{25}{ }_{\mathrm{D}}:-49.4\left(c=1.0, \mathrm{CHCl}_{3}\right)$. Anal. Calcd for $\mathrm{C}_{10} \mathrm{H}_{15^{-}}$ $\mathrm{NO}_{3}$ : C, 60.90; H, 7.67; N, 7.10. Found: C, 60.37; H, 7.44; N, 6.55 .

(6R)-7-[2-(3,4-Methylenedioxyphenyl)ethyl]-1,4-dioxa7-azadispiro[4.0.4.3]tridecan-8-one (10). To a solution of 9 (0.31 g, $1.57 \mathrm{mmol})$ in anhydrous benzene $(5 \mathrm{~mL}, 0.3 \mathrm{M})$ was added $\mathrm{NaH}(60 \mathrm{mg}, 2.50 \mathrm{mmol})$ portionwise. The mixture was refluxed for $5 \mathrm{~min}$ and then cooled to rt. Solid toluene-4sulfonic acid 2-benzo[1,3]dioxol-5-ylethyl ester ${ }^{11}$ (0.90 g, 2.81 mmol) was added, and the mixture was heated at reflux for $16 \mathrm{~h}$. The reaction mixture was poured into an aqueous saturated solution of $\mathrm{NH}_{4} \mathrm{Cl}$ and extracted with $\mathrm{CH}_{2} \mathrm{Cl}_{2}$. The organic phase was dried over $\mathrm{Na}_{2} \mathrm{SO}_{4}$ and concentrated under vacuum. The crude product was purified by flash chromatography on silica gel $\left(\mathrm{CH}_{2} \mathrm{Cl}_{2} / \mathrm{MeOH} / \mathrm{Et}_{3} \mathrm{~N} 95 / 5 / 1\right)$, providing 10 $(449 \mathrm{mg}, 80 \%)$ as a white solid. $\mathrm{Mp}=88{ }^{\circ} \mathrm{C}\left(i-\mathrm{Pr}_{2} \mathrm{O}\right) .{ }^{1} \mathrm{H}$ NMR $\left(300 \mathrm{MHz}, \mathrm{CDCl}_{3}\right): \delta=1.27(\mathrm{~m}, 3 \mathrm{H}), 1.55-1.75(\mathrm{~m}, 4 \mathrm{H}), 1.89$ $(\mathrm{m}, 1 \mathrm{H}), 2.08(\mathrm{~m}, 1 \mathrm{H}), 2.24(\mathrm{dd}, J=12.6,9.7 \mathrm{~Hz}, 1 \mathrm{H}), 2.32$ $(\mathrm{dd}, J=12.2,10.0 \mathrm{~Hz}, 1 \mathrm{H}), 2.59(\mathrm{~m}, 1 \mathrm{H}), 2.67(\mathrm{~m}, 1 \mathrm{H}), 2.83$ (ddd, $J=13.0,9.9,4.7 \mathrm{~Hz}, 1 \mathrm{H}), 3.34$ (ddd, $J=13.7,10.0,7.0$ $\mathrm{Hz}, 1 \mathrm{H}), 3.67(\mathrm{~m}, 1 \mathrm{H}), 3.7-3.85(\mathrm{~m}, 4 \mathrm{H}), 5.89(\mathrm{~s}, 2 \mathrm{H}), 6.66(\mathrm{~d}$, $J=7.9 \mathrm{H}, 1 \mathrm{~Hz}), 6.72(\mathrm{~s}, 1 \mathrm{H}), 6.73(\mathrm{~d}, J=7.9 \mathrm{~Hz}, 1 \mathrm{H}) .{ }^{13} \mathrm{C}$ NMR $\left(75 \mathrm{MHz} \mathrm{CDCl}_{3}\right.$ ): $\delta=16.9,30.5,31.7,32.9,33.8,35.1$, 44.1, 64.9, 65.9, 71.2, 101.1, 108.4, 109.7, 118.6, 122.1, 133.7, 146.2, 147.8, 176.7. IR (KBr): $v=2945,2884,1682,1491,1444$ $\mathrm{cm}^{-1}$. MS $\left(\mathrm{CI}, \mathrm{NH}_{3}\right): m / z=346\left([\mathrm{MH}]^{+}\right) .[\alpha]^{25}{ }_{\mathrm{D}}:-41.9(c=$ 1.27, $\mathrm{CHCl}_{3}$ ). Anal. Calcd for $\mathrm{C}_{19} \mathrm{H}_{23} \mathrm{NO}_{5}$ : C, 66.07; $\mathrm{H}, 6.71$; N, 4.06. Found: C, 66.35; H, 6.68; N, 3.85.

(5R)-1-[2-(3,4-Methylenedioxyphenyl)ethyl]-1-azaspiro[4.4]nonane-2,6-dione (11). A solution of 10 (3.80 g, 11.00 $\mathrm{mmol})$ in a water/acetic acid $9 / 1$ mixture $(56 \mathrm{~mL}, 0.2 \mathrm{M})$ was refluxed for $16 \mathrm{~h}$ and then cooled to $\mathrm{rt}$. The mixture was poured into an aqueous saturated solution of $\mathrm{NaHCO}_{3}$ and extracted with $\mathrm{CH}_{2} \mathrm{Cl}_{2}$. The organic phase was washed with brine, dried over $\mathrm{Na}_{2} \mathrm{SO}_{4}$, and concentrated under vacuum, providing $\mathbf{1 1}$ (3.45 g, quant) as a yellow oil. ${ }^{1} \mathrm{H}$ NMR $\left(300 \mathrm{MHz}, \mathrm{CDCl}_{3}\right): \delta$ $=1.67-1.85(\mathrm{~m}, 3 \mathrm{H}), 1.92-2.17(\mathrm{~m}, 4 \mathrm{H}), 2.30-2.45(\mathrm{~m}, 3 \mathrm{H})$, $2.57-2.74(\mathrm{~m}, 2 \mathrm{H}), 3.03$ (ddd, $J=13.4,10.3,6.5 \mathrm{~Hz}, 1 \mathrm{H}), 3.38$ (ddd, $J=13.5,10.0,5.1 \mathrm{~Hz}, 1 \mathrm{H}), 5.91(\mathrm{~s}, 2 \mathrm{H}), 6.62(\mathrm{~d}, J=7.6$ $\mathrm{Hz}, 1 \mathrm{H}), 6.67(\mathrm{~s}, 1 \mathrm{H}), 6.71(\mathrm{~d}, J=7.6 \mathrm{~Hz}, 1 \mathrm{H}),{ }^{13} \mathrm{C} \mathrm{NMR}(75$ $\left.\mathrm{MHz} \mathrm{CDCl}_{3}\right): \delta=17.6,29.2,29.9,33.6,34.9,35.2,43.8,72.5$, $101.1,108.6,109.6,122.0,133.1,146.4,148.0,176.2,217.1$. IR (film): $v=2963,2888,1745,1685,1503,1491,1443,1403$, 1247, $1037 \mathrm{~cm}^{-1}$. MS(CI, NH $\left.\mathrm{N}_{3}\right): \mathrm{m} / z=302\left([\mathrm{MH}]^{+}\right) .[\alpha]^{25} \mathrm{D}$ : $-13.6\left(c=0.72, \mathrm{CHCl}_{3}\right)$. Anal. Calcd for $\mathrm{C}_{17} \mathrm{H}_{19} \mathrm{NO}_{4} \cdot 1 /{ }_{2} \mathrm{H}_{2} \mathrm{O}$ : C, 65.79; H, 6.50; N, 4.51. Found: C, 65.63; H, 6.24; N, 4.53 .

Cephalotaxine (1). To a cooled $\left(0^{\circ} \mathrm{C}\right)$ solution of $\mathbf{1 8}(62$ $\mathrm{mg}, 0.19 \mathrm{mmol})$ in anhydrous THF $(1 \mathrm{~mL})$ was added a cooled $\left(0{ }^{\circ} \mathrm{C}\right) 1 \mathrm{M}$ solution of $\mathrm{AlH}_{3}$ in THF $(3 \mathrm{~mL}, 3 \mathrm{mmol}$, prepared from solid $\mathrm{AlCl}_{3}$ and $1 \mathrm{M} \mathrm{LiAlH}_{4}$ in THF). The reaction mixture was stirred for $2.5 \mathrm{~h}$, treated at $0{ }^{\circ} \mathrm{C}$ by wet $\mathrm{Na}_{2} \mathrm{SO}_{4}$, and filtered after loss of color. The solids were thoroughly washed with distilled THF, and the filtrate was concentrated under vacuum. The crude product was purified by flash chromatography on silica gel $\left(\mathrm{CH}_{2} \mathrm{Cl}_{2} / \mathrm{MeOH} / \mathrm{NH}_{4} \mathrm{OH} 95 / 5 / 0.5\right)$, providing $1(45 \mathrm{mg}, 75 \%)$ as a white solid. ${ }^{1} \mathrm{H}$ NMR (400 $\left.\mathrm{MHz}, \mathrm{CDCl}_{3}\right)$ : $\delta=1.70(\mathrm{sl}, 1 \mathrm{H}), 1.72-1.80(\mathrm{~m}, 2 \mathrm{H}), 1.88(\mathrm{ddd}, J=11.5,8.0$, $4.0 \mathrm{~Hz}, 1 \mathrm{H}$ ), 2.01 (dd, $J=11.5,9.6 \mathrm{~Hz}, 1 \mathrm{H}$ ), 2.36 (dd, $J=14.4$, $6.9 \mathrm{~Hz}, 1 \mathrm{H}), 2.53-2.66(\mathrm{~m}, 2 \mathrm{H}), 2.92(\mathrm{ddd}, J=11.8,11.3,7.1$ $\mathrm{Hz}, 1 \mathrm{H}), 3.07$ (m, 1H), 3.36 (ddd, $J=14.1,12.3,7.8 \mathrm{~Hz}, 1 \mathrm{H})$, $3.68(\mathrm{~d}, J=9.4 \mathrm{~Hz}, 1 \mathrm{H}), 3.73(\mathrm{~s}, 3 \mathrm{H}), 4.76(\mathrm{~d}, J=9.1 \mathrm{~Hz}, 1 \mathrm{H})$, $4.93(\mathrm{~s}, 1 \mathrm{H}), 5.91(\mathrm{~s}, 2 \mathrm{H}), 6.65(\mathrm{~s}, 1 \mathrm{H}), 6.68(\mathrm{~s}, 1 \mathrm{H}) .{ }^{13} \mathrm{C} \mathrm{NMR}$ 
$\left(75 \mathrm{MHz}, \mathrm{CDCl}_{3}\right): \delta=20.6,32.0,43.9,48.9,54.2,57.5,58.3$, $70.9,73.6,97.9,101.2,110.6,112.9,128.3,134.6,146.4,147.2$, 160.8. IR (film): $v=3522,2939,2880,2799,1651,1504,1486$, $1222,1038 \mathrm{~cm}^{-1} .[\alpha]^{20}{ }_{\mathrm{D}}:-182\left(c=0.21, \mathrm{CHCl}_{3}\right) . \mathrm{HRMS}\left(\mathrm{ESI}^{+}\right.$, $[\mathrm{MH}]^{+}$): $\mathrm{m} / z$ calcd 316.1549 , found 316.1544. HPLC (DAICEL, Chiralpak AD, hexane/i-PrOH/Et $\left.{ }_{3} \mathrm{~N} 80 / 20 / 0.5\right): t_{\mathrm{R}}=11.4 \mathrm{~min}$.

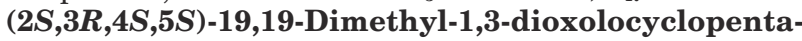
[4,5-c]cephalotaxane (21). A solution of diol $16(0.57 \mathrm{~g} ; 1.80$ $\mathrm{mmol}$ ) and $p$-toluenesulfonic acid (17 $\mathrm{mg}, 0.09 \mathrm{mmol})$ in acetone $(9 \mathrm{~mL})$ was stirred for $4 \mathrm{~h}$ at rt. Some product precipitated as a white solid and was filtered, rinsed with a small amount of acetone, and dried to give $230 \mathrm{mg}$ of $\mathbf{2 1}$. The solvent was removed in vacuo and the residue dissolved in dichloromethane. The organic phase was washed with an aqueous saturated $\mathrm{NaHCO}_{3}$ solution, dried over $\mathrm{Na}_{2} \mathrm{SO}_{4}$, and filtered, and the solvent was distilled off. The crude reaction mixture was purified by flash chromatography on silica gel $\left(\mathrm{CH}_{2} \mathrm{Cl}_{2} / \mathrm{MeOH} / \mathrm{NH}_{4} \mathrm{OH} 95 / 5 / 0.5\right)$, providing $319 \mathrm{mg}$ of 21 as a white solid. Then, $549 \mathrm{mg}(86 \%)$ of 21 was obtained as a white solid. $\mathrm{Mp}=188-190{ }^{\circ} \mathrm{C}\left(\mathrm{Et}_{2} \mathrm{O}\right) .{ }^{1} \mathrm{H}$ NMR $\left(400 \mathrm{MHz}, \mathrm{CDCl}_{3}\right)$ : $\delta=1.31(\mathrm{~s}, 3 \mathrm{H}), 1.59(\mathrm{~s}, 3 \mathrm{H}), 2.10-2.28(\mathrm{~m}, 5 \mathrm{H}), 2.60(\mathrm{dd}, J=$ $15.5,5.8 \mathrm{~Hz}, 1 \mathrm{H}$ ), 2.69 (ddd, $J=15.1,7.0,1.6 \mathrm{~Hz}, 1 \mathrm{H}$ ), 2.78 (ddd, $J=14.9,12.0,6.7 \mathrm{~Hz}, 1 \mathrm{H}), 3.03(\mathrm{dd}, J=13.7,6.2 \mathrm{~Hz}$ $1 \mathrm{H}), 3.16(\mathrm{~d}, J=5.2 \mathrm{~Hz}, 1 \mathrm{H}), 4.08$ (ddd, $J=13.8,11.8,7.1$ $\mathrm{Hz}, 1 \mathrm{H}), 4.67(\mathrm{t}, J=5.4 \mathrm{~Hz}, 1 \mathrm{H}), 4.79(\mathrm{dt}, J=5.6,2.7 \mathrm{~Hz}$, $1 \mathrm{H}), 5.89(\mathrm{~s}, 2 \mathrm{H}), 6.61(\mathrm{~s}, 1 \mathrm{H}), 6.63(\mathrm{~s}, 1 \mathrm{H}) .{ }^{13} \mathrm{C} \mathrm{NMR}(75 \mathrm{MHz}$, $\left.\mathrm{CDCl}_{3}\right): \delta=25.8,28.4,30.3,30.8,38.3,39.3,41.5,65.4,70.9$, $80.1,88.1,101.4,111.0,111.4,111.8,129.2,131.5,146.9,147.4$, 175.1. IR (film): $v=2978,2938,1686,1506,1489,1400,1371$, $1275,1248,1213 \mathrm{~cm}^{-1}$. $[\alpha]^{25} \mathrm{D}+69.0\left(c=0.63, \mathrm{CHCl}_{3}\right)$. HRMS $\left(\mathrm{ESI}^{+},[\mathrm{MH}]^{+}\right): \mathrm{m} / z$ calcd 380.1474 , found 380.1471 .

General Alkylation Procedure of Lactam 21. A solution of lactam 21 (200 mg; $0.56 \mathrm{mmol})$ in dry THF $(5.6 \mathrm{~mL})$ was cooled to $-78{ }^{\circ} \mathrm{C}$ under an argon atmosphere. A solution of $1.4 \mathrm{M} s$-BuLi $(0.60 \mathrm{~mL}, 0.84 \mathrm{mmol})$ in cyclohexane was slowly added (via syringe) to the mixture, and stirring was continuted for 20 min at $-78{ }^{\circ} \mathrm{C}$. Alkyl halide (3 equiv) was then slowly added to the mixture, which was stirred for $1 \mathrm{~h}$ at low temperature. The reaction was quenched by addition of brine, the cooling bath was removed, and the mixture was allowed to rise to room temperature. The aqueous phase was separated and extracted with $\mathrm{CH}_{2} \mathrm{Cl}_{2}$, and the organic phases, joined, were dried over $\mathrm{Na}_{2} \mathrm{SO}_{4}$. After evaporation of the solvent, the oily residue was purified by flash chromatography on silica gel using AcOEt as solvent.

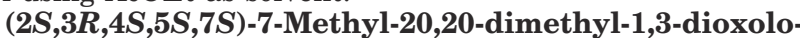
cyclopenta[4,5-c]cephalotaxan-8-one (22a). Colorless oil $(165 \mathrm{mg} ; 79 \%) .{ }^{1} \mathrm{H}$ NMR $\left(400 \mathrm{MHz}, \mathrm{CDCl}_{3}\right): \delta=1.09(\mathrm{~d}, J=$ $3 \mathrm{~Hz}, 3 \mathrm{H}), 1.32(\mathrm{~s}, 3 \mathrm{H}), 1.61(\mathrm{~s}, 3 \mathrm{H}), 1.83(\mathrm{t}, J=11.7 \mathrm{~Hz}, 1 \mathrm{H})$, $2.15-2.24(\mathrm{~m}, 2 \mathrm{H}), 2.53(\mathrm{dd}, J=12.3,7.6 \mathrm{~Hz}, 1 \mathrm{H}), 2.61(\mathrm{dd}, J$ $=14.8,6.4 \mathrm{~Hz}, 1 \mathrm{H}), 2.70-2.82(\mathrm{~m}, 2 \mathrm{H}), 3.07(\mathrm{dd}, J=13.6,6.3$ $\mathrm{Hz}, 1 \mathrm{H}), 3.20(\mathrm{~d}, J=4.8 \mathrm{~Hz}, 1 \mathrm{H}), 4.15(\mathrm{dd}, J=13.2,6.7 \mathrm{~Hz}$, $1 \mathrm{H}), 4.64(\mathrm{t}, J=5.0 \mathrm{~Hz}, 1 \mathrm{H}), 4.79(\mathrm{dt}, J=5.5,2.2 \mathrm{~Hz}, 1 \mathrm{H})$, $5.88(\mathrm{~s}, 2 \mathrm{H}), 6.60(\mathrm{~s}, 1 \mathrm{H}), 6.62(\mathrm{~s}, 1 \mathrm{H}),{ }^{13} \mathrm{C}$ NMR $(75 \mathrm{MHz}$, $\left.\mathrm{CDCl}_{3}\right): \delta=25.8,28.4,31.0,35.8,38.3,41.8,49.7,65.2,68.5$, $80.2,88.7,101.4,111.0,111.4,111.6,128.8,132.5,146.9,147.4$, 177.1. IR (film): $v=2983,2934,1682,1487,1217,1037 \mathrm{~cm}^{-1}$. $[\alpha]^{20}{ }_{\mathrm{D}}+47.0\left(c=1.35, \mathrm{CHCl}_{3}\right) . \operatorname{HRMS}\left(\mathrm{ESI}^{+},[\mathrm{MNa}]^{+}\right): \mathrm{m} / z$ calcd 394.1630 , found 394.1642 .

$(2 S, 3 R, 4 S, 5 S, 7 R)$-7-Methyl-20,20-dimethyl-1,3-dioxolocyclopenta[4,5-c]cephalotaxan-8-one (23a). Colorless oil (38 mg; 18\%). ${ }^{1} \mathrm{H}$ NMR (400 MHz, $\mathrm{CDCl}_{3}$ ): $\delta=1.04(\mathrm{~d}, J=7$ $\mathrm{Hz}, 3 \mathrm{H}), 1.32(\mathrm{~s}, 3 \mathrm{H}), 1.59(\mathrm{~s}, 3 \mathrm{H}), 1.70$ (dd, $J=12.2,9.7 \mathrm{~Hz}$, $1 \mathrm{H}), 2.25(\mathrm{dd}, J=15.4,2.5 \mathrm{~Hz}, 1 \mathrm{H}), 2.37-2.45(\mathrm{~m}, 2 \mathrm{H}), 2.54$ (dd, $J=12.3,8.3 \mathrm{~Hz}, 1 \mathrm{H}), 2.75$ (ddd, $J=15.0,7.2,2.6 \mathrm{~Hz}$, $1 \mathrm{H}), 2.85(\mathrm{~m}, 1 \mathrm{H}), 3.04$ (ddd, $J=13.2,4.6,1.6 \mathrm{~Hz}, 1 \mathrm{H}), 3.10$ $(\mathrm{d}, J=5.7 \mathrm{~Hz}, 1 \mathrm{H}), 3.97$ (ddd, $J=13.6,11.4,7.2 \mathrm{~Hz}, 1 \mathrm{H}$ ), $4.72(\mathrm{t}, J=5.6 \mathrm{~Hz}, 1 \mathrm{H}), 4.79(\mathrm{dd}, J=5.6,2.6 \mathrm{~Hz}, 1 \mathrm{H}), 5.89$ $(2 \mathrm{~s}, 2 \mathrm{H}), 6.62(\mathrm{~s}, 1 \mathrm{H}), 6.63(\mathrm{~s}, 1 \mathrm{H}) .{ }^{13} \mathrm{C} \mathrm{NMR}\left(75 \mathrm{MHz}, \mathrm{CDCl}_{3}\right)$ : $\delta=16.0,25.8,28.5,30.6,35.6,38.8,41.0,46.5,65.7,69.6,80.0$, 87.4, 101.4, 111.0, 112.0, 128.7, 130.3, 146.7, 178.0. IR (film): $v=2984,2934,1682,1504,1488,1372,1215,1038 \mathrm{~cm}^{-1} \cdot[\alpha]^{20}{ }_{\mathrm{D}}$ : $+85.6\left(c=1.90, \mathrm{CHCl}_{3}\right) . \mathrm{HRMS}\left(\mathrm{ESI}^{+},[\mathrm{MNa}]^{+}\right): \mathrm{m} / z$ calcd 394.1630, found 394.1636.

(7S)-7-Methylcephalotaxine (30a). Colorless oil (35 mg, $77 \%) .{ }^{1} \mathrm{H}$ NMR $\left(400 \mathrm{MHz}, \mathrm{CDCl}_{3}\right): \delta=1.00(\mathrm{~d}, J=6.9 \mathrm{~Hz}$, $3 \mathrm{H}), 1.61(\mathrm{dd}, J=11.5,4.5 \mathrm{~Hz}, 1 \mathrm{H}), 1.64(\mathrm{~d}, J=3.3 \mathrm{~Hz}, 1 \mathrm{H})$, $2.15-2.28(\mathrm{~m}, 3 \mathrm{H}), 2.33(\mathrm{dd}, J=14.4,6.8 \mathrm{~Hz}, 1 \mathrm{H}), 2.66$ (dd, $J$ $=10.8,7.9 \mathrm{~Hz}, 1 \mathrm{H}), 2.86(\mathrm{ddd}, J=11.8,11.4,7.1 \mathrm{~Hz}, 1 \mathrm{H})$, $3.08(\mathrm{dd}, J=7.4,6.1 \mathrm{~Hz}, 1 \mathrm{H}), 3.32(\mathrm{ddd}, J=14.2,12.2,7.8$ $\mathrm{Hz}, 1 \mathrm{H}), 3.63(\mathrm{~d}, J=9.4 \mathrm{~Hz}, 1 \mathrm{H}), 3.74(\mathrm{~s}, 3 \mathrm{H}), 4.74(\mathrm{dd}, J=$ $9.3,2.8 \mathrm{~Hz}, 1 \mathrm{H}), 4.93(\mathrm{~s}, 1 \mathrm{H}), 5.91(\mathrm{~s}, 2 \mathrm{H}), 6.63(\mathrm{~s}, 1 \mathrm{H}), 6.66(\mathrm{~s}$, 1H). ${ }^{13} \mathrm{C}$ NMR (75 MHz, $\left.\mathrm{CDCl}_{3}\right): \delta=20.7,29.2,32.1,48.2$, $53.1,57.5,60.2,63.1,70.7,73.4,99.8,101.2,110.7,112.9,128.7$, 134.4, 146.4, 147.1, 160.4. IR (film): $v=3546,2924,1654$, $1502,1486,1458,1340,1221,1039 \mathrm{~cm}^{-1} \cdot[\alpha]^{25}{ }_{\mathrm{D}}:-158.1(c=$ $\left.1.85, \mathrm{CHCl}_{3}\right)$. HRMS $\left(\mathrm{ESI}^{+},[\mathrm{MH}]^{+}\right): \mathrm{m} / z$ calcd 330.1705 , found 330.1719

(7S)-7-Butylcephalotaxine (30b). Colorless oil $(76 \mathrm{mg}$, 93\%). ${ }^{1} \mathrm{H}$ NMR $\left(400 \mathrm{MHz}, \mathrm{CDCl}_{3}\right): \delta=0.88(\mathrm{t}, J=7.1 \mathrm{~Hz}$, $3 \mathrm{H}), 1.17-1.36(\mathrm{~m}, 6 \mathrm{H}), 1.60-1.68(\mathrm{~m}, 2 \mathrm{H}), 2.06(\mathrm{~m}, 1 \mathrm{H}), 2.18-$ $2.30(\mathrm{~m}, 2 \mathrm{H}), 2.31(\mathrm{dd}, J=14.4,6.9 \mathrm{~Hz}, 1 \mathrm{H}), 2.65(\mathrm{dd}, J=$ $10.7,8.0 \mathrm{~Hz}, 1 \mathrm{H}), 2.87$ (ddd, $J=11.8,11.3,7.0 \mathrm{~Hz}, 1 \mathrm{H}$ ), 3.06 (t, $J=8.3 \mathrm{~Hz}, 1 \mathrm{H}), 3.32$ (ddd, $J=14.1,12.4,7.7 \mathrm{~Hz}, 1 \mathrm{H}), 3.64$ (d, $J=9.4 \mathrm{~Hz}, 1 \mathrm{H}), 3.73(\mathrm{~s}, 3 \mathrm{H}), 4.74(\mathrm{dd}, J=9.3,3.3 \mathrm{~Hz}$, $1 \mathrm{H}), 4.92(\mathrm{~s}, 1 \mathrm{H}), 5.90(\mathrm{~s}, 2 \mathrm{H}), 6.63(\mathrm{~s}, 1 \mathrm{H}), 6.66(\mathrm{~s}, 1 \mathrm{H}) .{ }^{13} \mathrm{C}$ NMR $\left(75 \mathrm{MHz} \mathrm{CDCl}_{3}\right.$ ): $\delta=14.4,23.1,30.9,32.1,34.8,36.0$, $48.3,51.5,57.6,60.2,61.8,68.3,73.4,99.7,101.2,110.7,113.0$, 128.7, 134.4, 146.4, 150.5, 160.3. IR (film): $v=3537,2954$, $1647,1502,1483,1219,1039 \mathrm{~cm}^{-1} .[\alpha]^{25} \mathrm{D}-157.8(c=0.76$, $\mathrm{CHCl}_{3}$ ). HRMS $\left(\mathrm{ESI}^{+},[\mathrm{MH}]^{+}\right): \mathrm{m} / z$ calcd 372.2175 , found 372.2160 .

(7S)-7-Benzylcephalotaxine (30c). Colorless oil (42 mg,

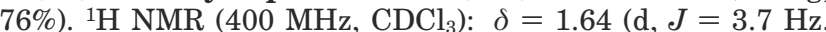
$1 \mathrm{H}), 1.76(\mathrm{dd}, J=13.0,6.0 \mathrm{~Hz}, 1 \mathrm{H}), 2.17(\mathrm{dd}, J=13.0,9.3$ $\mathrm{Hz}, 1 \mathrm{H}), 2.33(\mathrm{dd}, J=14.4,6.7 \mathrm{~Hz}, 1 \mathrm{H}), 2.40-2.51(\mathrm{~m}, 2 \mathrm{H})$, $2.63-2.75(\mathrm{~m}, 3 \mathrm{H}), 2.87$ (ddd, $J=11.8,11.4,7.0 \mathrm{~Hz}, 1 \mathrm{H}), 3.01$ (dd, $J=8.1,6.7 \mathrm{~Hz}, 1 \mathrm{H}), 3.32$ (ddd, $J=14.3,12.2,7.9 \mathrm{~Hz}$, $1 \mathrm{H}), 3.62(\mathrm{~d}, J=9.4 \mathrm{~Hz}, 1 \mathrm{H}), 3.75(\mathrm{~s}, 1 \mathrm{H}), 4.73(\mathrm{dd}, J=9.3$, $3.4 \mathrm{~Hz}, 1 \mathrm{H}), 4.92(\mathrm{~s}, 1 \mathrm{H}), 5.89(\mathrm{~s}, 2 \mathrm{H}), 6.62(\mathrm{~s}, 1 \mathrm{H}), 6.66(\mathrm{~s}$, $1 \mathrm{H}), 7.16(\mathrm{~d}, J=6.9 \mathrm{~Hz}, 2 \mathrm{H}), 7.20(\mathrm{~d}, J=7.5 \mathrm{~Hz}, 1 \mathrm{H}), 7.28(\mathrm{t}$, $J=7.0 \mathrm{~Hz}, 1 \mathrm{H}) .{ }^{13} \mathrm{C} \mathrm{NMR}\left(75 \mathrm{MHz}, \mathrm{CDCl}_{3}\right): \delta=32.1,36.4$, 41.7, 48.1, 50.9, 57.6, 60.3, 61.2, 70.5, 73.4, 99.7, 101.2, 110.7, $112.9,126.2,128.6,128.7,129.0,134.4,141.2,146.4,147.1$, 160.5. IR (film): $v=3546,2925,1654,1502,1486,1340,1039$ $\mathrm{cm}^{-1} \cdot[\alpha]^{25} \mathrm{D}:-131.9\left(c=2.10, \mathrm{CHCl}_{3}\right) . \operatorname{HRMS}\left(\mathrm{ESI}^{+},[\mathrm{MH}]^{+}\right)$: $\mathrm{m} / \mathrm{z}$ calcd 406.2018 , found 406.2023.

(7R)-7-Methylcephalotaxine (31a). Colorless oil (14 mg,

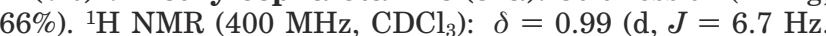
$3 \mathrm{H}), 1.61(\mathrm{bs}, 1 \mathrm{H}), 1.63-1.74(\mathrm{~m}, 2 \mathrm{H}), 1.95(\mathrm{dd}, J=11.7,7.4$ $\mathrm{Hz}, 1 \mathrm{H}), 2.25(\mathrm{~m}, 1 \mathrm{H}), 2.35(\mathrm{dd}, J=14.4,6.7 \mathrm{~Hz}, 1 \mathrm{H}), 2.62$ (dd, $J=10.2,8.0 \mathrm{~Hz}, 1 \mathrm{H}), 2.70-2.90(\mathrm{~m}, 2 \mathrm{H}), 3.30$ (ddd, $J=$ $14.3,12.0,7.6 \mathrm{~Hz}, 1 \mathrm{H}), 3.65(\mathrm{~d}, J=9.3 \mathrm{~Hz}, 1 \mathrm{H}), 3.73(\mathrm{~s}, 3 \mathrm{H})$, $4.72(\mathrm{dd}, J=9.1,1.1 \mathrm{~Hz}, 1 \mathrm{H}), 4.95(\mathrm{~s}, 1 \mathrm{H}), 5.92(\mathrm{~s}, 2 \mathrm{H}), 6.64$ (s, $1 \mathrm{H}), 6.67(\mathrm{~s}, 1 \mathrm{H}) .{ }^{13} \mathrm{C} \mathrm{NMR}\left(75 \mathrm{MHz}, \mathrm{CDCl}_{3}\right): \delta=20.6$, $29.3,32.2,49.0,52.9,57.5,58.3,61.5,72.1,73.4,98.7,101.2$, $110.6,112.9,128.5,134.6,146.3,147.1,160.7$. IR (film): $v=$ $3517,2926,2881,2795,1648,1484,1221,1037 \mathrm{~cm}^{-1} \cdot\left[\alpha{ }^{25} \mathrm{D}\right.$ : $-134.4\left(c=0.70, \mathrm{CHCl}_{3}\right)$.

Acknowledgment. This research was supported by the CNRS and the MENRT. We thank Prof. B. Bodo and Dr. A. Jossang from the "Museum National d'Histoire Naturelle" (Paris) for a gift of natural (-)cephalotaxine. 